\title{
Here, there and everywhere - the importance of neutral lipids in plant growth and development
}

\section{dr hab. Agnieszka Zienkie- wicz, prof. UMK,}

\section{mgr Marta Saldat,}

\section{dr hab. Krzysztof Zienkie- wicz, prof. UMK ${ }^{\otimes}$}

Centre for Modern Interdisciplinary Technologies, Nicolaus Copernicus University in Torun, Torun, Poland

https://doi.org/10.18388/pb.2021_409

$\bowtie$ Corresponding author:kzienk@umk.pl

Key words: lipid droplets, triacylglycerol, neutral lipids, seed, pollen, leaf senescence.

Abbreviations: FFA - free fatty acids; DAG - diacylglycerol; DGAT - diacylglycerol acyltransferase; ER - endoplasmic reticulum; LD lipid droplet; TAGs - triacylglycerol.

\begin{abstract}
In plants, lipids serve as one of the major and vital cellular constituents. Neutral lipids reserves play an essential role in plant life cycle by providing carbon and energy equivalents for periods of active metabolism. The most common form of lipid storage are triacylglycerols (TAGs) packed into specialized organelles called lipid droplets (LDs). They have been observed in diverse plant organs and tissues, like oil seeds or pollen grains. LDs consist of a core, composed mostly of TAGs, enclosed by a single layer of phospholipids that is decorated by a unique set of structural proteins. Moreover, the recent advances in exploration of LDs proteome revealed a plethora of diverse proteins interacting with LDs. This is likely the result of a highly dynamic nature of these organelles and their involvement in many diverse aspects of cellular metabolism, tightly synchronized with plant developmental programs and directly related to plant-environment interactions. In this review, we summarize and discuss the current progress in understanding the role of LDs and their cargo during plant life cycle, with a special emphasis on developmental aspects.
\end{abstract}

\section{INTRODUCTION}

Lipids are a very diverse group of organic cellular compounds that are essential for a plethora of biological functions in prokaryotic and eukaryotic cells, including membrane structural organization, carbon and energy storage or cell signaling [1]. Such functional diversity of lipids is reflected in the variety of their structures. In plants, for the purposes of simplicity, the two most general levels of lipid classification are structural lipids and storage lipids. Internal structural lipids play a fundamental role in cell organization, being building blocks for cellular membranes [2,3]. This group of lipids is represented mostly by phospholipids, composed of two hydrophobic fatty acid "tails" esterified with glycerol and a hydrophilic "head" consisting of a phosphate group, as well as glycolipids comprised of a hydrophobic lipid "tails" and one or more hydrophilic sugar groups linked by a glycosidic bond [2].

Storage lipids in plants are represented mainly by triacylglycerols (TAGs), which at the chemical level are esters of glycerol backbone and three fatty acid tails. Such chemical structure and composition of TAGs indicates their predominant role in eukaryotic cells, namely, being a reservoir of cellular carbon and energy. In the following sections of this review, a more detailed focus will be given to this lipid class, with a special emphasis on their synthesis, metabolism and roles in diverse aspects of plant growth and development.

Most of our current knowledge on plant storage lipid metabolism in plant cells comes from studies on oilseeds, with Arabidopsis thaliana as the standard reference with respect to genetic and biochemical mechanisms governing TAGs synthesis and accumulation [4]. Consequently, reconstruction of these pathways in other plant species and plant cell types is mostly based on genome predictions and orthologous relationship to lipid metabolism-related genes. In plant cells, lipid synthesis starts in plastids, where fatty acids (FAs) are generated. FAs, usually as coenzyme A (CoA) conjugates (acyl-CoAs), are exported to the cytosol. They serve as essential acyl donors for synthesis of TAGs, which takes place in endoplasmic reticulum (ER) and is catalyzed by ER membrane residing enzymes [5] (Fig. 1).

Based on the orthology of the genes involved in TAG synthesis identified so far in plants, it has been shown that TAGs can be synthesized by several diverse pathways, of which the glycerol 3-phosphate (or Kennedy) pathway is the major one [4]. It starts with glycerol 3 phosphate (G-3-P), which is successively esterified with the acyl chain of acylo-CoAs. These reactions occur in a specific manner and are catalyzed by specific acyltransferases located in the ER membrane (Fig. 1). In the first reaction, catalyzed by glycerol-3-phosphate acyltransferase 


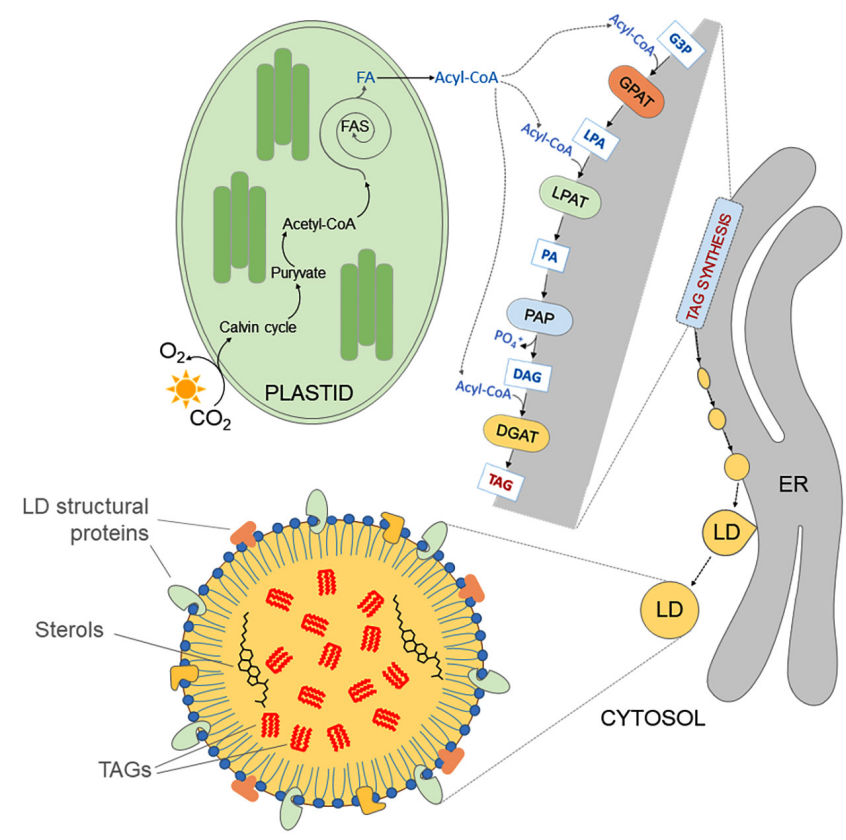

Figure 1. Major TAGs synthesis pathway and LDs formation process in plant cells. Abbreviations: CoA, coenzyme A; DAG, diacylglycerol; DGAT, acylCoA:diacylglycerol acyltransferase, ER, endoplasmic reticulum; FA, fatty acid; FAS, fatty acid synthase, G-3-P, glycerol-3-phosphate; GPAT, acylCoA:glycerol-3-phosphate acyl transferase; LD, lipid droplet; LPA, lysophosphatidic acid; LPAT, acyl-CoA:lysophosphatidic acid acyl transferase; PA, phosphatidic acid; PAP, phosphatidic acid phosphatase; TAG, triacylglycerol.

(GPAT), G-3-P is linked to acylo-CoA and lysphosphatidic acid (LPA) is generated. LPA after esterification with another acylo-CoA is converted into phosphatidic acid (PA). This reaction is catalyzed by lysophosphatidate acyltransferase (LPAT). PA can serve as a substrate for synthesis of phospholipids or TAGs. In the latter case, dephosphorylation of PA by phosphatidic acid phosphatase (PAP) leads to formation of diacylglycerol (DAG). DAGs are further converted into TAGs by acyl CoA:diacylglycerol acyltransferase (DGAT) and this reaction is considered a committed step of TAGs formation in eukaryotic cells [5,6]. TAGs synthesized at the ER membrane are then deposited in spherical organelles known in the literature under diverse terms, of which lipid droplets (LDs), oil bodies (OBs) and oleosomes are the most common [7-9]. For consistency and simplicity, the term lipid droplets (LDs) will be used in the following sections to describe them.

The assembly of LDs starts with deposition of TAGs in the ER bilayer in the form of lens. As TAGs concentration increases, membrane-packing defects caused by increasing volume of TAGs accumulating between the leaflets of the ER bilayer are recognized by amphiphatic helices of SEIPIN protein complex, which facilitates and controls the growth of LDs into the cytoplasm [10]. SEIPIN2 and SEIPIN3 proteins from Arabidopsis thaliana contain at their N-termini phenylalanine-acidic tract (FFAT) motifs, which serve to interact with AtVAP27-1 protein. The interaction between these proteins is necessary for a proper formation of mature LDs, which finally detach from ER and localize to the cytosol [10]. Mature cytoplasmic LDs are spherical organelles composed of a phospholipid monolayer that surrounds a hydrophobic core of neutral lipids, mostly TAGs, with much smaller amounts of diacylglycerols (DAGs) and sterol esters $[8,9]$. The phospholipid monolayer of LDs is precisely spotted/speckled with specific proteins. These proteins are more or less tightly bound to the surface of LDs and play essential role in their biogenesis, trafficking and mobilization $[9,11]$. Large number of LDs-associated proteins has been identified in various proteomics analyses performed on LDs isolated from diverse plant tissues [8]. In order to better understand their function, LDs-associated proteins were divided into two main classes; class I includes proteins stably associating with ER membranes and recruited to the surface of LDs during their biogenesis, and class II which comprises proteins recruited to the LDs surface from the cytosol. The proteins from class I usually associate with the LDs membranes by their central hydrophobic domain, meanwhile their C- and N-termini face the cytosol. The LDs proteins of class II in turn may directly interact with other LDs-associating proteins or with LDs phospholipid monolayer through a lipid anchor [9].

Until recently LDs were considered as a simple storage compartment for TAGs, however their intense studies of the last two decades revealed that they represent highly dynamic structures, actively involved in diverse physiological processes, regulation of cellular energy homeostasis, remodeling of cellular membranes and numerous signaling pathways [12-14]. Moreover, they have been involved in diverse metabolic routes, functioning of multiple organelles as well as in many developmental programs. Below we provide a current view on the role of LDs in plant growth and development, with a special emphasis on their turnover and role in cellular metabolism in diverse types of plant cells.

\section{SEED LIPID DROPLETS - THE BEGINNING OF AN ERA}

In higher plants, the proper seed development and formation is a key to successful propagation of species. Seed formation is tightly associated with accumulation of storage compounds including starch, lipids and proteins in various parts of the seed. In oleaginous species, such as Arabidopsis, the main seed storage compounds are oils in the form of TAGs which are stored in LDs. These organelles are massively mobilized during first steps of seed germination and serve as a major carbon and energy source for a proper seedling growth prior to photosynthetic establishment.

The first basics of our current knowledge on the function and metabolism of LDs came from original studies in oilseeds, which were studied extensively decades before mammals and microbes. This includes the first efforts to characterize the proteins that specifically associate with seed LDs carried out at the end of the last century. This knowledge and advances made in the past 20 years to characterize these extraordinary organelles at molecular and cellular level showed that the function, stability and dynamics of seed LDs depends mainly on three major class I LDs-associated proteins - oleosins, caleosins, and steroleosins $[5,8]$. In Arabidopsis, five seed-specific types of oleosins were reported to be associated with LDs. The nomenclature of oleosins was designated based on their abundance in mature seed. Therefore, the most abundant oleosin is OLE1, 
followed by OLE2, OLE3, OLE4 and OLE5 [15,16]. OLEs, as typical class I proteins, associate with the phospholipid monolayer of LDs through the hydrophobic central domain containing a proline knot motif. This domain is responsible for their anchoring in the TAGs matrix of LDs. Meanwhile, the hydrophilic C- and N-terminal domains of OLEs are exposed to the cytoplasm $[17,18]$. The analysis of Arabidopsis mutants demonstrated that loss of function of OLE1 leads to the accumulation of larger LDs, when compared to wild type seeds $[15,19]$. Interestingly, oleosins deficiency in ole1 ole3 and ole1 ole 2 double mutants was correlated with even larger LDs than those observed in ole1 seeds [15]. Thus, it has been proposed that oleosins are implicated in the control of the size and spatial distribution of LDs, by preventing their abnormal fusion during seed development $[15,20]$. Changes in the size and distribution patterns of LDs observed in oleosin mutants had small but significant impact on seed lipid content and composition [19,20]. Moreover, delay in seed germination was observed in the oleosin mutants, especially in ole 1 ole 3 and ole 1 ole2, which contained the lowest level of oleosins among all the analyzed mutants. In addition, after freezing treatment the seeds of ole1 ole 3 and ole1 ole 2 failed to germinate, unlike the wild type seeds [15]. These observations suggest that oleosins are essential not only for seeds performance but also for their freezing tolerance. Similar to oleosins, caleosins are considered as structural proteins of seed LDs. When compared to oleosins, caleosins possess larger hydrophilic N-terminal domain with a single EF-hand calcium binding motif, one central hydrophobic domain and hydrophilic C-terminus with a few potential phosphorylation sites [21-23]. Both, $\mathrm{N}$ - and C-termini of caleosin face the cytosol and contain heme-binding sites with conserved histidine residues. The ability of caleosins to bind calcium and the fact that they possess peroxigenase activity suggest that these proteins are probably not only simple structural proteins of LDs, but also might be involved in signaling events related to lipid metabolism. In Arabidopsis genome, eight genes encoding caleosins have been identified. These were divided into two types, L-caleosins (CLO4-CLO7) and H-caleosins (CLO1-3, CLO8), based on their molecular weight [24]. Two Arabidopsis caleosin-encoding genes - CLO1 and CLO2 are highly and specifically expressed during seed development, suggesting that their protein products could be implicated in the biogenesis of seed LDs [24]. Indeed, it was demonstrated that CLO1 is the most abundant caleosin present in the seeds LDs of $A$. thaliana [25]. Besides CLO1, recent analysis of LDs proteome from seeds showed also the presence of CLO2 in LDs fraction isolated at subsequent stages of their development, germination and seedling growth [26]. Trace amounts of two other caleosins - CLO3 and CLO5 were as well detected in the protein fraction of LDs isolated at two stages of seed development [26]. Interestingly, AtCLO1 loss of function didn't affect seed germination rates, however it had an impact on LDs mobilization as the TAGs degradation in Atclo1 mutant was delayed when compared to wild type plants [25]. Thus, it has been proposed that CLO1 plays a significant role in LDs degradation rather than in LDs formation. Steroleosins were the third, however minor, protein class identified in seed LDs proteome in A. thaliana $[26,27]$. Unlike oleosins and caleosins, steroleosins possess only two domains: an N-terminal hydrophobic region with a proline knob motif responsible for LDs-anchoring, and a soluble sterol-binding dehydrogenase/reductase domain [28]. Arabidopsis stereoleosin, known as HYDROXYSTEROID DEHYDROGENASE1 (AtHSD1), has been identified in the proteome of LDs isolated from developing and mature seeds [26,29]. The overexpression of AtHSD1 leads to reduced seed dormancy and seed yield when compared to wild type seeds $[27,30]$. No effect on fatty acids content or composition in the seeds of transgenic lines was detectable [27]. Interestingly, plants overexpressing AtHSD1 are however hypersensitive to brassinosteroids (BR) [30]. These results, together with the fact that AtHSD1 expression is induced by treatment with brassinolide (active BR), suggest that steroleosins might be implicated in the biosynthesis of BR and/or BR-mediated signaling pathways.

Mobilization of LDs during seed germination is associated with two main events: degradation of LDs-associated proteins and breakdown of the stored TAGs. In Arabidopsis, degradation of oleosins occurs via ubiquitin-proteasome pathway, however OLE2, OLE4 and OLE5 are degraded just prior to lipid hydrolysis, meanwhile degradation of OLE3 and OLE1 occurs at the onset of TAGs mobilization [16]. Recently, it has been demonstrated that plant UBX domaincontaining protein PUX10 associates with Arabidopsis seed LDs and binds via its UBA domain to ubiquitinated oleosins and by its UBX domain to CELL DIVISION CYCLE 48 HOMOLOG A (CDC48A) protein [31,32]. CDC48A plays essential role in the ER-associated degradation (ERAD) of misfolded proteins [33]. This interaction has been suggested to be crucial for dislocation of oleosins from LDs and their degradation in the proteasome [31,32]. Unfortunately, there is no data available on caleosin and steroleosin degradation mechanisms during seed germination.

In turn, hydrolysis of TAGs (lipolysis) into FAs, DAGs and MAGs by TAGs lipases seems to be the major pathway of LDs breakdown in plants. SUGAR DEPENDENT1 lipase (SDP1) has been shown to play a prominent role in mobilization of TAGs from LDs in germinating Arabidopsis seeds $[34,35]$. AtSDP1 loss of function leads to inhibition of TAGs breakdown and consequently hampers seedling development. The mobilization of TAGs starts when inactive form of AtSDP1 is translocated from the surface of peroxisomes into LDs surface via peroxules - dynamic extensions of peroxisomes [36]. FAs released from TAGs by the action of AtSDP1 are then transported by an ATP-binding cassette (ABC) transporter (AtPXA1) into peroxisomes where they enter $\beta$-oxidation process [37]. Until now, the analysis of diverse lipase mutants showed no significant differences in the TAGs breakdown rates during seed germination, compared to wild type plants. This fact strongly suggests that AtSDP1 is the main TAGs lipase involved in LDs breakdown process. In addition to lipolysis, a specific autophagy-related pathway (lipophagy) may also be implicated in the hydrolysis of TAGs. Such scenario has been proposed recently based on the observations that LDs are commonly localized in the vacuolar lumen of cotyledon cells during early stages of seedling establishment [25]. Notably, the lack of LDs inside the vacuoles was observed in Arabidopsis caleosin clo1 mutant and was correlated with a slower degradation of 
TAGs during seed germination [25]. Therefore, it has been proposed that some portion of LDs might also be degraded by caleosin-dependent autophagy during seed germination. The molecular aspects of this process are currently under investigation in our laboratory.

\section{LIPIDS IN POLLEN DEVELOPMENT - TWO FACES OF THE SAME COIN}

Anthers with developing pollen grains are the second most active site in TAGs biosynthesis after the seed [38]. The central part of the anther is the loculus where microspores develop into pollen grains. The loculus is surrounded by several somatic layers. The most inner layer of the anther is tapetum, which synthesizes and secretes diverse compounds to the locular space, like nutrients, metabolites and pollen wall precursors to promote pollen development [39]. The latter group of compounds includes the specific lipidic cargo, which finally will form pollen wall and pollen coat (PC), also referred to as pollenkit or tryphine [40]. The secretion of lipidic material by tapetal cells occurs in a precisely synchronized manner, however the type of lipidic cargo and cellular structures involved in this process change during the course of pollen development [41] (Fig. 2A).

During early stages of microspore development, the tapetal cells secrete specific type of small cytosolic organelles of lipidic character termed pro-orbicules or Ubisch bodies. They have been discovered more than 150 years ago, however despite of such a long history their role in tapetal or pollen development has not yet been fully addressed. This is mainly due to their very small size and relatively strong association with the tapetal cell wall. Moreover, no Ubisch bodies have been found in the leading plant experimental models like A. thaliana or Brassica species, which strongly hampers their deeper biochemical or molecular characteristics. However, based on their histochemical and microscopic studies in other species, it has been suggested that Ubisch bodies seem to carry lipidic precursors of sporopollenin, which after polymerization becomes an impermeable barrier that protects developing pollen grains from physical, biological and chemical factors [40,42]. During later steps of pollen development, tapetum produces mostly lipidic components of the pollen coat, which are gradually deposited into the exine cavities (Fig. 2A-B). They are transported by two types of LDs - plastoglobuli and tapetosomes $[38,40]$. Plastoglobuli are synthesized by tapetal elaioplasts and have been characterized in depth in Brassica species $[43,44]$. They are surrounded by a membrane and carry sterol esters, which further serve as a matrix of the pollen coat. Interestingly, this is the only reported example of sterol esters occurring in a non-cytosolic location [43]. Beside sterol esters, the LDs from elaioplasts store also FFAs and membrane lipids and are equipped with specific plastid-lipid associated proteins of 31-36 $\mathrm{kDa}$, depending on species [45]. In turn, tapetosomes are lipidic organelles specific to tapetal tissue and so far have also been observed and characterized mainly in Brassica species. Single tapetosome is of 2 to $3 \mu \mathrm{m}$ in diameter and composed of many LDs, spatially associated with membranous matrix $[44,46]$. Such specific architecture of tapetosomes is most probably a reflection of a unique mechanism of their synthesis. During early stages of anther development, the secretory tapetal cells are rich in ER cisternae where TAGs synthesis takes place and numer-
A

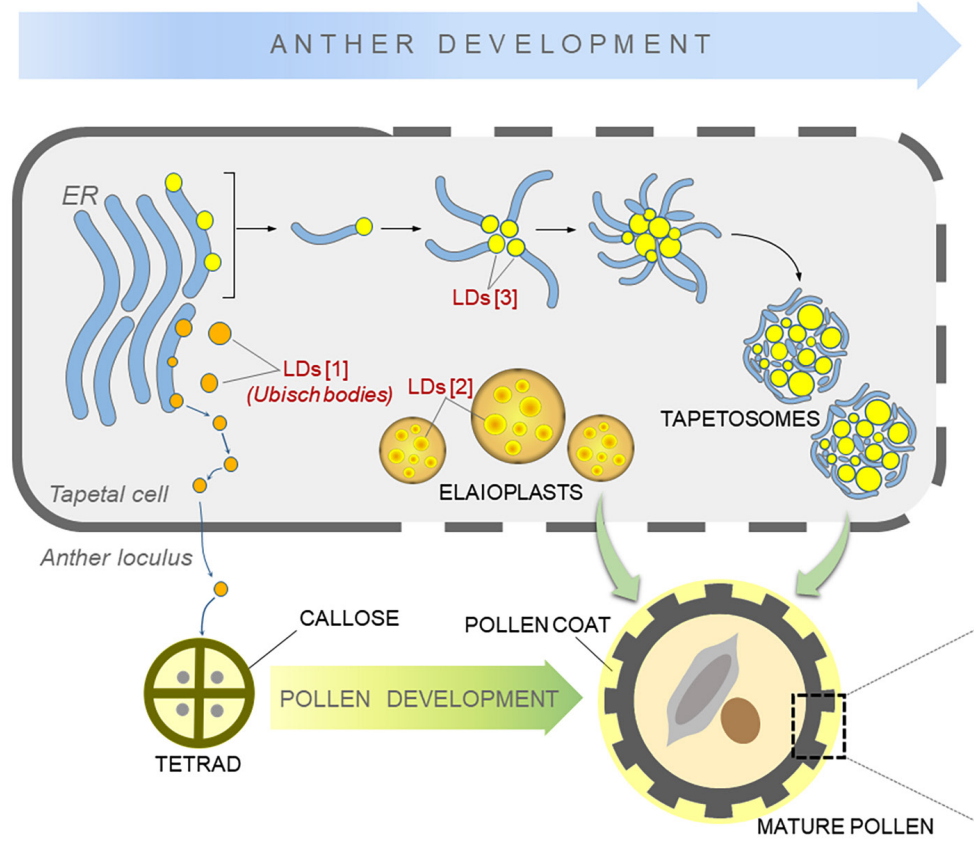

B

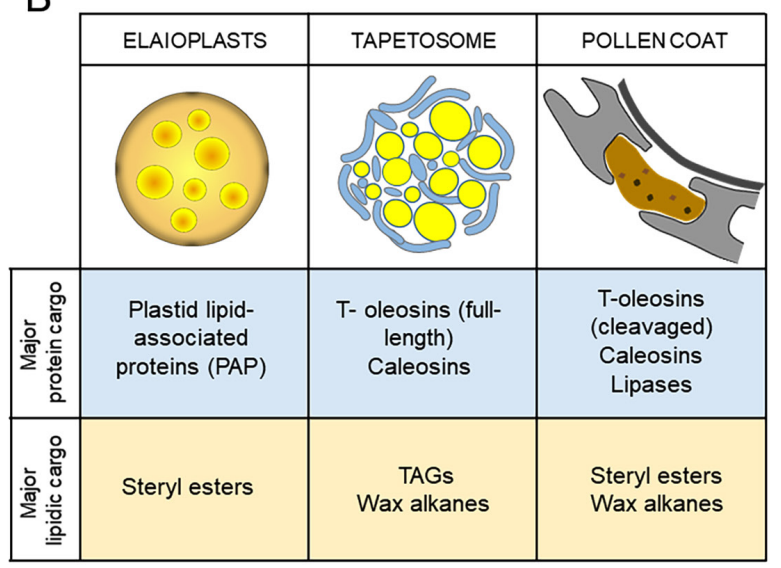

C

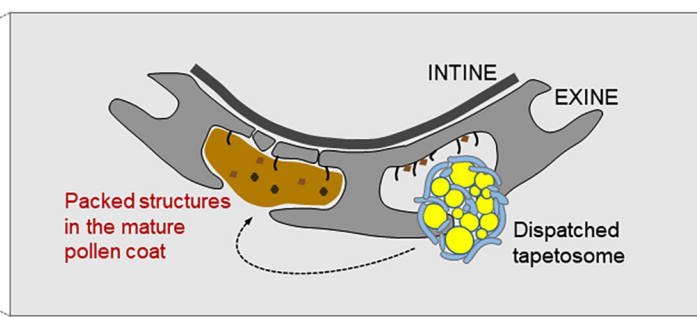

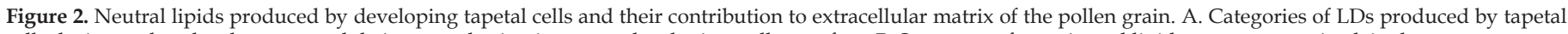

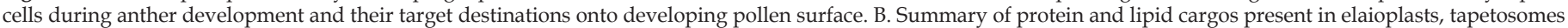
and mature pollen coat. C. Morphological transformation of tapetosome during pollen wall development. 
ous LDs are formed. This process seems to be analogical to LD synthesis in seeds [47]. However, unlike in seeds, LDs synthesis in tapetal cells is accompanied by intense production of numerous cisternae-like vesicles by the ER, which are linked together even after ER decomposition during tapetum degradation [48]. This spatial association is tough to be mediated by calreticulin and other binding proteins decorating the membrane of the cisternae-like vesicles [49]. As a result, mature tapetosome is a separate structure composed of numerous LDs embedded between a dense net of ER cisternae (Fig. 2A).

The lipidic cargo of tapetosomes includes TAGs stored in LDs as well as wax alkanes stored in ER, whereas major proteins associated with these structures contain oleosin domains, and thus are termed T-oleosins (Tapetal oleosins) [40]. T-oleosins are also known in the literature as glycinerich proteins (GLRPs) [50] or oleo-pollenins [7]. In most of plant species, the process of pollen development and pollen coat formation is temporally correlated with tapetum degradation. As tapetum degenerates, both elaioplasts and tapetosomes are released into the anther locule targeting their lipidic and protein cargos to the pollen coat (Fig. 2A-B). The TAGs stored in LDs of tapetosomes are likely degraded as the majority of the lipids identified in the pollen coat seem to be derived from elaioplasts [40]. The pollen coat of mature pollen is composed of long- and short-chain lipids accompanied by oleosins and other specific proteins [51]. Importantly, once tapetosomes come into contact with the wall of developing pollen, T-oleosins undergo specific endoproteolytic cleavage at or near the junction between the oleosin-like domain and the remaining C-terminal domain, resulting in high variability with respect to the amino acid composition [40]. Early proteomics studies of the pollen coat in A. thatiana and several species of the genus Brassica revealed that pollen coat-associated T-oleosins form quite heterogenous group but their common feature is the presence of an oleosin-like domain [40]. This domain is also shared by oleosins from seeds and has been proposed to be responsible for their targeting to the tapetosomes and most probably to play a role in maintaining the structural integrity of these structures. In turn, the C-terminal domain released from the full length T-oleosins by endopeptidases after tapetal cell lysis becomes tightly associated with other pollen coat components. The cleavage itself is suggested to be one of the mechanisms enabling the change of tapetosome morphology to more compact once fused with the exine structures (Fig. 2C) [40].

Interestingly, beside T-oleosins the proteome of pollen coat from diverse plant species have been found to contain many other proteins, indicating more complex nature of this extracellular matrix. Among them, caleosins have been found in such diverse species like A. thaliana [52], Brassica napus [40], Olea europaea [53,54] or Zea mays [55]. Similar to $\mathrm{T}$-oleosins, caleosins present in the pollen coat have been suggested to have tapetal origin $[53,54]$. Additionally, the presence of EF-hand $\mathrm{Ca}^{2+}$-binding domain, several phosphorylation sites and lipid-binding domain suggests that pollen coat-associated caleosins might have a function in pollen-stigma signaling [40].
It is beyond doubt that both, lipid and lipid-associated protein components of the pollen coat have essential functions in pollen protection and pollination. It has been proposed that steryl esters delivered in LDs from elaioplasts form a waterproof barrier protecting mature pollen grain from its dehydration before reaching the receptive stigma and are directly involved in the adhesion of the pollen grain to the stigmatic surface [51]. Mutations affecting genes involved in their biogenesis lead to impaired development of tapetal elaioplasts and tapetosomes, and in consequence to deficient formation of pollen coat and strongly reduced pollen performance [56]. Moreover, disruptions in the synthesis of the pollen coat lipids, especially the long-chain ones, strongly affect pollen hydration $[57,58]$. The process of water uptake by the pollen is thought to be regulated not only by pollen coat lipids but also pollen coat proteins. Indeed, Mayfield and Preuss (2000) showed that mutation in the gene encoding one of the major pollen coat T-oleosins designated as GRP17-1 in A. thaliana results in a severe impairment of pollen hydration and consequently makes the mutants unable to pollinate [59]. More recent identification of extracellular lipases in the pollen coat proteome and their functional characteristics revealed that most probably they act together with T-oleosins to modify lipid composition at the pollen-stigma interface $[52,60]$. As the result, the permeability of the cuticle and the pollen coating changes, thus enabling the diffusion of water from the stigma to the desiccated pollen.

Regardless of the events occurring in the sporophytic tissues of the anther, microspores/pollen grains follow their own developmental program designed to prepare the mature pollen grains for delivering male gametes to the cells of female gametophyte. During the long period of pollen maturation, pollen grains of many plants accumulate storage lipids $[38,53,54,61]$, likely to mobilize them during energydemanding process of pollen tube growth [62]. The accumulation of lipids takes place mainly in the vegetative pollen cell and reaches the highest rates soon after the vacuolation stage of the microspore and leads to gradual increase of LDs number, with the maximum at pollen maturity $[53,54,63]$. Such pattern of lipid accumulation in developing pollen grains seems to be rather common for flowering plants, as it has been observed in such diverse species like Brassica [64], Arabidopsis [65], tobacco [66], olive [53,61] or lily [67]. The lipid synthesis and accumulation occurring during pollen development is crucial for normal pollen development as mutations of the key genes involved in TAG biosynthesis result in male sterility of plants. Zhang et al. (2009) showed that double knockout mutation in the genes encoding major TAG-producing enzymes - phosphatidyl:diacylglycerol acyltransferase 1 (PDAT1) and diacylglycerol acyltransferase 1 (DGAT1), results not only in a strong reduction of pollen LDs pool but also in abortion of around $50 \%$ of pollen grains soon after microspore mitosis. Interestingly, the abnormal pollen grains deficient in LDs had normal extracellular lipids. These results confirm that the precursors of extracellular pollen lipids are determined by the sporophytic tapetum and indicate that internal pollen lipids are determined by expression of the haploid genome of pollen [68]. 
In developing pollen, the synthesis of TAGs and LDs biogenesis likely takes place in specialized domains of ER. Indeed, pollen LDs were often found in the direct contact with ER cisternae [54]. Thus, the cellular mechanisms of LDs synthesis in pollen cells seems to be similar to those of oilseeds. This is suggested not only by their close spatial relationship with ER cisternae but also by the identification of pollen specific counterparts of seed LDs-associated proteins - oleosins and caleosins $[53,67,69,70]$. No pollen-specific steroleosin has been however found in LDs purified from pollen grains. Expression of oleosin-encoding genes has been confirmed in microspores/pollen grains of A. thaliana [69] and lily [67]. In turn, pollen specific caleosin proteins have been described in lily [70], olive [53,54] and more recently in cycas [71] and pine [72]. Our studies in olive showed also that the pollen specific caleosin is expressed mainly in the vegetative cell and that its levels gradually increase during pollen maturation, reaching the highest levels at pollen maturity, concurrently with the number of LDs [54]. These observations suggest that, similar to the seed caleosin, the pollen inner caleosin may also be involved in LDs biogenesis during pollen maturation. On the other hand, pollen oleosins and caleosins seem to be slightly different from their seed counterparts at molecular level as they are of different size. However, to date, no knockout mutants affected in these genes have been published to elucidate the function of the corresponding proteins in pollen development and performance.

By analogy to seeds, LDs stored in mature pollen serve most probably as a major energy and carbon source for a rapid pollen tube growth. This assumption is supported by a gradual decrease of LDs number just after pollen hydration and during pollen tube growth, likely illustrating the process of their mobilization [53,62]. As the rapid elongation of the pollen tube demands energy production and intense biosynthetic capacity [73], the TAGs stored in pollen LDs would serve not only as energy-rich substrate but also as building blocks for intense membrane synthesis [53,62,74]. The studies on LDs metabolism in germinating pollen and during pollen tube growth are however few and fragmentary. Our observations in olive showed that LDs mobilization in the pollen grain seems to be triggered just right after its hydration. This process begins from relocation of LDs into a close proximity to the aperture of hydrated pollen grain and their entering into the emerging pollen tube once the germination process starts $[53,61,62]$. During the whole course of pollen tube growth, the pool of LDs gradually decreases until their complete mobilization.

The cellular aspects of LDs mobilization in germinating pollen have been studied only in a few species. In olive growing pollen tubes LDs seem to spatially interact with ER structures [75], whereas in lily they were also found to be present in the vacuoles [70]. Such spatial distribution suggests that both, ER and vacuoles might be involved in LDs degradation. Interestingly, the fusion of LDs have been reported for germinating seeds of $A$. thaliana and suggested as one of the mechanisms of LDs mobilization [25]. The authors proposed also caleosin as the key player in this process. Our studies in olive growing pollen tubes indicated also that caleosin could be directly involved in LDs degradation in germinating pollen [53]. Our hypothesis is based on the presence of caleosin in both, the intracellular membranes and in the tonoplast, as well as on a gradual depletion of its pool during pollen tube growth, concurrently with decreasing number of LDs.

The molecular events accompanying LDs degradation during pollen germination and pollen tube growth are yet not fully deciphered. Studies on the enzymatic machinery directly involved in mobilization of pollen LDs are limited only to a few species, including $A$. thaliana, tobacco and olive. AtSDP1L was the first identified putative TAG lipase of particularly high expression in mature pollen grains of A. thaliana, suggesting its involvement in LDs breakdown upon pollen germination [35]. More recently, Müller and Ischebeck (2018) showed that other TAG lipase - AtOBL1 localizes to LDs in pollen tubes and its mutation results in a slower pollen tube growth in vivo in Arabidopsis [76]. LD-associated lipase, phospholipase A and lipoxygenase activities were also found on the surface of LDs present in germinating pollen and in growing pollen tubes of olive $[62,77]$. However, meanwhile phospholipase A activity was observed on the LDs surface at pollen maturity and after germination, the lipase activity and lipoxygenase protein were associated with LDs only when pollen germination is already in progress [62]. Thus, the proposed scenario of LDs mobilization during olive pollen germination is that phospholipase A is recruited to the pollen LDs prior to pollen maturity and promotes the fast access of lipase and lipoxygenase to the TAGs core of LDs after the water uptake by the pollen grain and during pollen germination. The biological rationale of such scenario is supported by the fact that the initiation of pollen germination and pollen tube growth occurs very fast, thus the localization of the lipid enzymatic machinery on the surface of LDs in mature pollen grain might guarantee the rapid mobilization of storage lipids as the pollen germination starts. Moreover, the differences in spatio-temporal recruitment of the enzymes involved in LDs breakdown observed between pollen grain and seed may results from their diverse energy demands, tightly connected with their biological role.

\section{STORE OR NOT TO STORE - LIPID DROPLETS IN VEGETATIVE TISSUES}

Until recently, it has been generally accepted that the cells of vegetative tissues, such as leaves or stems, do not have ability to accumulate TAGs. Nevertheless, the number of LDs significantly increases during Arabidopsis leaf senescence [78]. Moreover, the number of LDs in the leaf is regulated also by diurnal cycle, reaching the highest amount at the end of the night and the lowest at the end of the day [79]. Recently, it was demonstrated that lipid droplet-associated protein1 (LDAP1) and one of the caleosins isoform CLO3, also known as RESPONSIVE TO DEHYDRATION20 (RD20), are the most abundant structural proteins of LDs from Arabidopsis leaves during senescence [78]. The Arabidopsis genome encodes three LDAPs proteins: LDAP1, LDAP2, LDAP3 [79]. Overexpression of all the LDAPs-encoding genes results in accumulation of LDs in the leaves at the end of the day, meanwhile the LDAP-disrupted lines were characterized by less abundant LDs in the leaves at 
the end of the night [79]. Recently, it has been proposed that the LDAP proteins play a significant role in LDs biogenesis in the leaves. During initial steps of LDs formation, LDAPinteracting protein (LDIP) interacts with SEIPIN on the ER lumenal side, enabling the accumulation of TAGs between the leaflets of the ER bilayer [80]. As TAGs continues to accumulate, LDIP dissociates from the complex with SEIPIN and is translocated on the nascent LDs surface were it interacts with LDAP protein. Based on these data, it seems that interactions between LDIP and SEIPIN as well as between LDIP and LDAP proteins are essential for LDs biogenesis at ER and indicate that the machinery responsible for this process might be different from oil storing tissues/organs, like seed or pollen, where oleosins are the key players in the process of LDs formation $[8,80]$.

Emerging evidences suggest that LDs accumulate not only in senescing leaves but also in response to biotic and abiotic stresses [81]. Indeed, under abiotic stresses, such as heat or cold, increased synthesis of TAGs and LDs formation is observed in leaves [79]. They accumulate TAGs under heat stress likely to remove the excess of toxic FFAs, such as a-linolenic acid (18:3) released from cellular membranes. Recently, it was demonstrated that HEAT INDUCIBLE LIPASE1 (HIL1) is implicated in the turnover of monogalactosyldiacylglycerol (MGDG), the major chloroplast membrane lipid under heat stress, which leads to the synthesis of 18:3-containing TAGs [82]. The ability of plants to resist freezing stress is as well associated with increased conversion of DAGs to TAGs and with up-regulation of DGAT1 expression [83,84]. In Arabidopsis, a significant increase in the number of leaf LDs observed in response to cold was associated with a strong induction of LDAP1 and LDAP3 expression [79]. On the other hand, the higher accumulation of LDs in the leaf in response to high temperature was correlated with the increased expression of LDAP1 but not of LDAP2 and LDAP3. Thus, different proteins from LDAP family might participate in the formation of LDs under diverse stress conditions. Interestingly, the expression of CLO3 - the leaf LDs specific caleosin, is as well strongly induced in response to abiotic stresses [85]. Moreover, the mutation in CLO3-encoding gene enhanced stomatal opening and led to reduced tolerance to drought [85]. It has been also shown that CLO3 plays an important role in the biosynthesis of oxylipins, which are directly implicated in plant response to pathogen attack $[86,87]$. The infection of Arabidopsis plants with the fungal pathogen Colletotrichum higginisianum induced the localization of a-dioxygenase 1 (a-DOX1) on the surface of leaf LDs and formation of 2-hydroperoxy-octadecatrienoic acid (2-HPOT) from a-linolenic acid released from TAGs. Then, CLO3 converts 2-HPOT into 2-hydroxyoctadecatrienoic acid (2-HOT), which has antifungal activity against Colletrichum spp. [87]. Additionally, the accumulation of LDs containing CYP71A12, CYP71A13 and PAD3 (PHYTOALEXIN DEFICIENT3) proteins was observed after Pseudomonas syringae pv tomato (Pst) DC3000 avrRpm1 infection of Arabidopsis leaves [88]. Three other proteins directly involved in plant resistance to herbivores and pathogens were also identified in the proteomic analyses of LDs isolated from Arabidopsis aging leaves. These were STRICTOSIDINE SYNTHASE (STR), 2-OXOGLUTARATE AND FE(II)-DEPENDENT OXYGENASE and NITRILE SPECI-

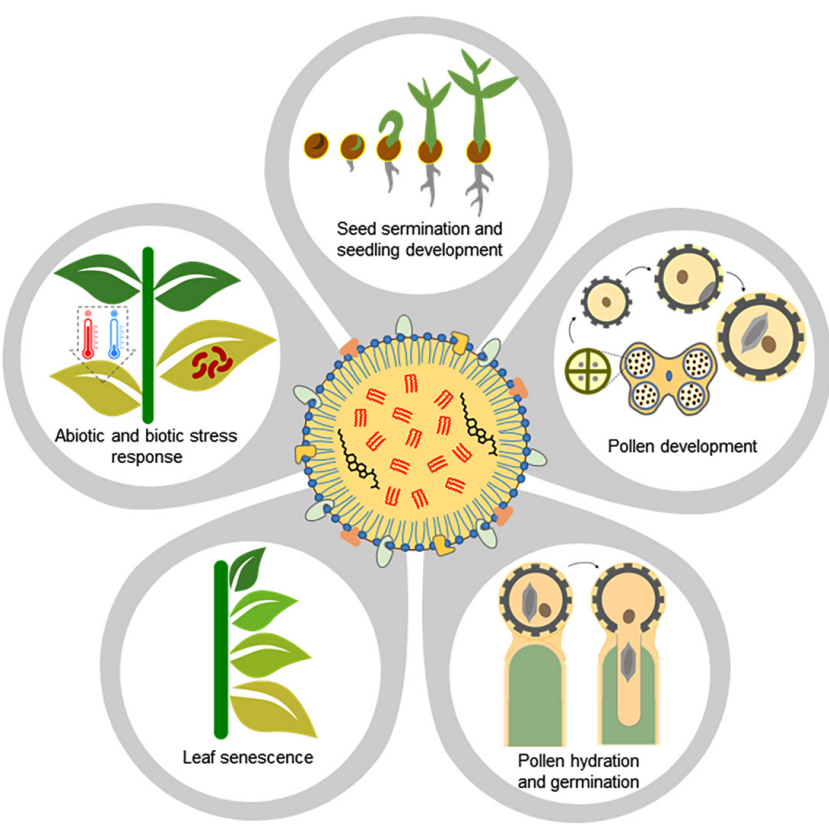

Figure 3. Schematic representation of plant developmental and physiological processes involving neutral lipids stored in LDs.

FIER PROTEIN5 (NSP5) [78]. Many pathogens are using stomata as a gate for penetration and plant infection [89]. Recently, it was reported that LDs localized in guard cells serve as energy source necessary to light-induced stomatal opening [90]. Interestingly, the studies of stomata in potato leaves before and after infection by Phytophthora infestans showed that the pathogen attack not only induces stomatal opening but is also accompanied by the degradation of TAGs in guard cells [91]. These recent observations open a new line of research directly connecting the metabolism of LDs and TAGs with plant defense response.

Overall, it seems likely that the dynamics and metabolism of LDs in the leaves is more intense than those of their seed or pollen counterparts. This is mainly due to the fact that in most of plants leaf is not a storage organ, but the major receptor of external stimuli, including biotic and abiotic factors. This in turn requires efficient cellular signaling systems and rapid responses at cellular level. Thus, leaf LDs might serve as a cellular mediator for diverse metabolic and signaling pathways involving lipids. Nevertheless, our understanding of LDs metabolism and function in leaves is still only fragmentary. Thus, upcoming research will be rather focused on LDs proteome in these organs, especially under stress conditions, in order to identify new specific LDs proteins and their role in LDs-mediated processes in plants.

\section{CONCLUDING REMARKS AND FUTURE PERSPECTIVES}

The present review outlines the essential role of neutral lipids in plant life cycles, starting from the earliest steps of seed germination, going through subsequent phases of plant growth and its interaction with environment, and ending up with sexual reproduction (Fig. 3). The studies of the last two decades revealed that plant LDs, beside common general structure, seem to be rather tissue/organ-spe- 
cific in terms of their protein equipment and function. The recent advances in plant LDs proteome research strongly support this hypothesis and indicate much complex and more advanced role for these organelles than was previously thought. Similar to their animal and human counterparts, plant LDs have been re-discovered as dynamic cellular organelles and not simple oil storage depots. As in case of other cellular organelles, the life cycle of LDs, including their biogenesis, maturation, degradation and interactions with other organelles, is highly synchronized with developmental and physiological states of the plant. Regardless of the recent progress in deciphering the nature of plant LDs, many aspects of their lifecycle and role remain incompletely understood especially. This is especially true for non-seed tissues. Thus, the major challenges for upcoming research on plant LDs should include: 1) deeper mapping of proteomes and interactomes of LDs under diverse stresses, 2) gaining detailed knowledge related to the lifecycle of LDs in non-seed tissues, 3) matching the molecular mechanisms linking the lifecycle of LDs with plant developmental programs. Reaching the above goals will definitively lead to better understanding not only the role of LDs as metabolically important organelles but also to explore yet unknown pathways involving neutral lipids in plant cells.

\section{REFERENCES:}

1. Ridgway N, McLeod R (2016) Biochemistry of lipids, lipoproteins and membranes. Sixth edition. Elsevier, UK

2. Yuki N (2017) Plant Phospholipid Diversity: Emerging Functions in Metabolism and Protein-Lipid Interactions. Trends Plant Sci 22: 10271040

3. Mamode Cassim A, Gouguet P, Gronnier J, Laurent N, Germain V, Grison M, Boutté Y, Gerbeau-Pissot P, Simon-Plas F, Mongrand S. (2019) Plant lipids: Key players of plasma membrane organization and function. Prog Lipid Res 73: 1-27

4. Li-Beisson Y et al. (2013) Acyl-lipid metabolism. Arabidopsis Book 11: e0161

5. Chapman KD, Ohlrogge JB (2012) Compartmentation of triacylglycerol accumulation in plants. J Biol Chem 287: 2288-2294

6. Harris CA, Haas JT, Streeper RS, Stone SJ, Kumari M, Yang K, Han X, Brownell N, Gross RW, Zechner R, Farese RV Jr (2011) DGAT enzymes are required for triacylglycerol synthesis and lipid droplets in adipocytes. J Lipid Res 52: 657-567

7. Murphy DJ (2001) The biogenesis and functions of lipid bodies in animals, plants and microorganisms. Prog Lipid Res 40: 325-438

8. Huang AHC (2018) Plant Lipid Droplets and Their Associated Proteins: Potential for Rapid Advances. Plant Physiol 176: 1894-1918

9. Olzmann JA, Carvalho P (2019) Dynamics and functions of lipid droplets. Nat Rev Mol Cell Biol 20: 137-155

10. Greer MS, Cai Y, Gidda SK, Esnay N, Kretzschmar FK, Seay D, McClinchie E, Ischebeck T, Mullen RT, Dyer JM, Chapman KD (2020) SEIPIN Isoforms Interact with the Membrane-Tethering Protein VAP271 for Lipid Droplet Formation. Plant Cell 32: 2932-2950

11. van der Schoot C, Paul LK, Paul SB, Rinne PL (2011) Plant lipid bodies and cell-cell signaling: a new role for an old organelle? Plant Signal Behav 6: 1732-1738

12. Pyc M, Cai Y, Greer MS, Yurchenko O, Chapman KD, Dyer JM, Mullen RT (2017) Turning Over a New Leaf in Lipid Droplet Biology. Trends Plant Sci 22: 596-609

13. Peter KL, Kiran-Kumar S, Roberto EC (2020) Lipid droplets throughout the evolutionary tree. Prog Lipid Res 78: 101029

14. Herker E, Vieyres G, Beller M, Krahmer N, Bohnert M (2021) Lipid Droplet Contact Sites in Health and Disease. Trends Cell Biol 31: 345358
15. Shimada TL, Shimada T, Takahashi H, Fukao Y, Hara-Nishimura I. (2008) A novel role for oleosins in freezing tolerance of oilseeds in Arabidopsis thaliana. Plant J 55: 798-809

16. Deruyffelaere C, Bouchez I, Morin H, Guillot A, Miquel M, Froissard M, Chardot T, D'Andrea S (2015) Ubiquitin-Mediated Proteasomal Degradation of Oleosins is Involved in Oil Body Mobilization During Post-Germinative Seedling Growth in Arabidopsis. Plant Cell Physiol 56: 1374-87

17. Napier JA, Beaudoin F, Tatham AS, Alexander LG, Shewry PR (2001) The seed oleosins: Structure, properties and biological role. Adv Bot Res 35: 111-138

18. Abell BM, Hahn M, Holbrook LA, Moloney MM (2004) Membrane topology and sequence requirements for oil body targeting of oleosin. Plant J 37: 461-470

19. Siloto RM, Findlay K, Lopez-Villalobos A, Yeung EC, Nykiforuk CL, Moloney MM (2006) The accumulation of oleosins determines the size of seed oilbodies in Arabidopsis. Plant Cell 18: 1961-1974

20. Miquel M, Trigui G, d'Andréa S, Kelemen Z, Baud S, Berger A, Deruyffelaere C, Trubuil A, Lepiniec L, Dubreucq B (2014) Specialization of oleosins in oil body dynamics during seed development in Arabidopsis seeds. Plant Physiol 164: 1866-1878

21. Chen JC, Tsai CC, Tzen JT (1999) Cloning and secondary structure analysis of caleosin, a unique calcium-binding protein in oil bodies of plant seeds. Plant Cell Physiol 40: 1079-1086

22. Naested H, Frandsen GI, Jauh GY, Hernandez-Pinzon I, Nielsen HB, Murphy DJ, Rogers JC, Mundy J (2000) Caleosins: $\mathrm{Ca}^{2+}$-binding proteins associated with lipid bodies. Plant Mol Biol 44: 463-476

23. Shao Q, Liu X, Su T, Ma C, Wang P (2019) New insights into the role of seed oil body proteins in metabolism and plant development. Front Plant Sci 10: 1568

24. Shen Y, Liu M, Wang L, Li Z, Taylor DC, Li Z, Zhang M (2016) Identification, duplication, evolution and expression analyses of caleosins in Brassica plants and Arabidopsis subspecies. Mol Gen Genom 291: 971-988

25. Poxleitner M, Rogers SW, Lacey Samuels A, Browse J, Rogers JC (2006) A role for caleosin in degradation of oil-body storage lipid during seed germination. Plant J 47: 917-933

26. Kretzschmar FK, Doner NM, Krawczyk HE, Scholz P, Schmitt K, Valerius O, Braus GH, Mullen RT, Ischebeck T (2020) Identification of Low-Abundance Lipid Droplet Proteins in Seeds and Seedlings. Plant Physiol 182: 1326-1345

27. Baud S, Dichow NR, Kelemen Z, d'Andréa S, To A, Berger N, Canonge M, Kronenberger J, Viterbo D, Dubreucq B, Lepiniec L, Chardot T, Miquel M (2009) Regulation of HSD1 in seeds of Arabidopsis thaliana. Plant Cell Physiol 50: 1463-1478.

28. Lin LJ, Tai SS, Peng CC, Tzen JT (2002) Steroleosin, a sterol-binding dehydrogenase in seed oil bodies. Plant Physiol 128: 1200-1211

29. Jolivet P, Roux E, d'Andrea S, Davanture M, Negroni L, Zivy M, Chardot T (2004) Protein composition of oil bodies in Arabidopsis thaliana ecotype WS. Plant Physiol Biochem 42: 501-509

30. Li F, Asami T, Wu X, Tsang EW, Cutler AJ (2007) A putative hydroxysteroid dehydrogenase involved in regulating plant growth and development. Plant Physiol 145: 87-97

31. Deruyffelaere C, Purkrtova Z, Bouchez I, Collet B, Cacas JL, Chardot T, Gallois JL, D' Andrea S (2018) PUX10 Is a CDC48A Adaptor Protein That Regulates the Extraction of Ubiquitinated Oleosins from Seed Lipid Droplets in Arabidopsis. Plant Cell 30: 2116-2136

32. Kretzschmar FK, Mengel LA, Müller AO, Schmitt K, Blersch KF, Valerius O, Braus GH, Ischebeck T (2018) PUX10 Is a Lipid Droplet-Localized Scaffold Protein That Interacts with CELL DIVISION CYCLE48 and Is Involved in the Degradation of Lipid Droplet Proteins. Plant Cell 30: 2137-2160

33. Liu Y, Li J (2014) Endoplasmic reticulum-mediated protein quality control in Arabidopsis. Front Plant Sci 5: 162

34. Eastmond PJ (2006) SUGAR-DEPENDENT1 encodes a patatin domain triacylglycerol lipase that initiates storage oil breakdown in germinating Arabidopsis seeds. Plant Cell 18: 665-675 
35. Kelly AA, Quettier AL, Shaw E, Eastmond PJ (2011) Seed storage oil mobilization is important but not essential for germination or seedling establishment in Arabidopsis. Plant Physiol 157: 866-875

36. Thazar-Poulot N, Miquel M, Fobis-Loisy I, Gaude T (2015) Peroxisome extensions deliver the Arabidopsis SDP1 lipase to oil bodies. Proc Natl Acad Sci 112: 4158-4163

37. Zolman BK, Silva ID, Bartel B (2001) The Arabidopsis pxa1 mutant is defective in an ATP-binding cassette transporter-like protein required for peroxisomal fatty acid beta-oxidation. Plant Physiol 127: 1266-1278

38. Piffanelli P, Ross JHE, Murphy DJ (1998) Biogenesis and function of the lipidic structures of pollen grains. Sex Plant Rep 11: 65-80

39. Goldberg RB, Beals TP, Sanders PM (1993) Anther development: basic principles and practical applications. Plant Cell 5: 1217-1229

40. Murphy DJ (2006) The extracellular pollen coat in members of the Brassicaceae: composition, biosynthesis, and functions in pollination. Protoplasma 228: 31

41. Parish RW, Li SF (2010) Death of a tapetum: A programme of developmental altruism. Plant Sci 178: 73-89

42. Huysmans S, El-Ghazaly G, Smets E (1998) Orbicules in angiosperms: Morphology, function, distribution, and relation with tapetum types. Bot Review 64: 240-272

43. Hernández-Pinzón I, Ross JH, Barnes KA, Damant AP, Murphy DJ (1999) Composition and role of tapetal lipid bodies in the biogenesis of the pollen coat of Brassica napus. Planta 208: 588-598

44. Wu SSH, Platt KA, Ratnayake C, Wang TW, Ting JTL, Huang AHC (1997) Isolation and characterization of neutral-lipid-containing organelles and globuli-filled plastids from Brassica napus tapetum. Proc Natl Acad Sci 94: 12711-12716

45. Kim HU, Wu SS, Ratnayake C, Huang AH (2001) Brassica rapa has three genes that encode proteins associated with different neutral lipids in plastids of specific tissues. Plant Physiol 126: 330-341

46. Hsieh K, Huang AH. 2005. Lipid-rich tapetosomes in Brassica tapetum are composed of oleosin-coated oil droplets and vesicles, both assembled in and then detached from the endoplasmic reticulum. Plant J 43: 889-899

47. Hsieh K, Huang AH (2004) Endoplasmic reticulum, oleosins, and oils in seeds and tapetum cells. Plant Physiol 136: 3427-3434

48. Suzuki T, Tsunekawa S, Koizuka C, Yamamoto K, Imamura J, Nakamura K, Ishiguro S (2013) Development and disintegration of tapetum-specific lipid-accumulating organelles, elaioplasts and tapetosomes, in Arabidopsis thaliana and Brassica napus. Plant Sci 207: 25-36

49. Hsieh K, Huang AHC (2007) Tapetosomes in brassica tapetum accumulate endoplasmic reticulum-derived flavonoids and alkanes for delivery to the pollen surface. Plant Cell 19: 582-596

50. de Oliveira DE, Franco LO, Simoens C, Seurinck J, Coppieters J, Botterman J, Van Montagu M (1993) Inflorescence-specific genes from Arabidopsis thaliana encoding glycine-rich proteins. Plant J 3:495-507

51. Rejón JD, Delalande F, Schaeffer-Reiss C, Alché JD, Rodríguez-García MI, Van Dorsselaer A, Castro AJ (2016) The Pollen Coat Proteome: At the Cutting Edge of Plant Reproduction. Proteomes 4: 5

52. Mayfield JA, Fiebig A, Johnstone SE, Preuss D (2001) Gene families from the Arabidopsis thaliana pollen coat proteome. Science 292: 24822485

53. Zienkiewicz K, Castro AJ, Alché Jde D, Zienkiewicz A, Suárez C, Rodríguez-García MI (2010) Identification and localization of a caleosin in olive (Olea europaea L.) pollen during in vitro germination. J Exp Bot 61: 1537-1546

54. Zienkiewicz K, Zienkiewicz A, Rodríguez-García MI, Castro AJ (2011) Characterization of a caleosin expressed during olive (Olea europaea L.) pollen ontogeny. BMC Plant Biol 11:122

55. Wu XL, Cai G, Gong FP, An SF, Cresti M, Wang W (2015) Proteome Profiling of Maize Pollen Coats Reveals Novel Protein Components. Plant Mol Biol Rep 33: 975-986

56. Ishiguro S, Nishimori Y, Yamada M, Saito H, Suzuki T, Nakagawa T, Miyake H, Okada K, Nakamura K (2010) The Arabidopsis FLAKY POLLEN1 gene encodes a 3-hydroxy-3-methylglutaryl-coenzyme A synthase required for development of tapetum-specific organelles and fertility of pollen grains. Plant Cell Physiol 51: 896-911

57. Preuss D, Lemieux B, Yen G, Davis RW (1993) A conditional sterile mutation eliminates surface components from Arabidopsis pollen and disrupts cell signaling during fertilization. Genes Dev 7: 974-985

58. Hulskamp M, Schneitz K, Pruitt RE (1995) Genetic evidence for a long-range activity that directs pollen tube guidance in arabidopsis. Plant Cell 7: 57-64

59. Mayfield JA, Preuss D (2000) Rapid initiation of Arabidopsis pollination requires the oleosin-domain protein GRP17. Nat Cell Biol 2: 128130

60. Updegraff EP, Zhao F, Preuss D (2009) The extracellular lipase EXL4 is required for efficient hydration of Arabidopsis pollen. Sex Plant Reprod 22: 197-204

61. Rodríguez-García MI, M’Rani-Alaoui M, Fernández MC (2003) Behavior of storage lipids during development and germination of olive (Olea europaea L.) pollen. Protoplasma 221: 237-244

62. Zienkiewicz A, Zienkiewicz K, Rejón JD, Rodríguez-García MI, Castro AJ (2013) New insights into the early steps of oil body mobilization during pollen germination. J Exp Bot 64: 293-302

63. McCormick S (1993) Male Gametophyte Development. Plant Cell 5: 1265-1275

64. Charzynska M, Murgia M, Cresti M (1989) Ultrastructure of the vegetative cell of Brassica napus pollen with particular reference to microbodies. Protoplasma 152: 22-28

65. Zheng Y, Deng X, Qu A, Zhang M, Tao Y, Yang L, Liu Y, Xu J, Zhang S (2018) Regulation of pollen lipid body biogenesis by MAP kinases and downstream WRKY transcription factors in Arabidopsis. PLoS Genet 14: e1007880

66. Rotsch AH, Kopka J, Feussner I, Ischebeck T (2017) Central metabolite and sterol profiling divides tobacco male gametophyte development and pollen tube growth into eight metabolic phases. Plant J 92: 129-146

67. Jiang PL, Wang CS, Hsu CM, Jauh GY, Tzen JT (2007) Stable oil bodies sheltered by a unique oleosin in lily pollen. Plant Cell Physiol 48: 812821

68. Zhang M, Fan J, Taylor DC, Ohlrogge JB (2009) DGAT1 and PDAT1 acyltransferases have overlapping functions in Arabidopsis triacylglycerol biosynthesis and are essential for normal pollen and seed development. Plant Cell 21(12): 3885-901.

69. Kim HU, Hsieh K, Ratnayake C, Huang AH. (2002) A novel group of oleosins is present inside the pollen of Arabidopsis. J Biol Chem 277(25): 22677-84

70. Jiang PL, Jauh GY, Wang CS, Tzen JT (2008) A unique caleosin in oil bodies of lily pollen. Plant Cell Physiol 49: 1390-1395

71. Pasaribu B, Fu JH, Jiang PL (2020) Identification and characterization of caleosin in Cycas revoluta pollen. Plant Signal Behav 15: 1779486

72. Pasaribu B, Chen CS, Liao YK, Jiang PL, Tzen JTC (2017) Identification of caleosin and oleosin in oil bodies of pine pollen. Plant Physiol Biochem 111: 20-29

73. Taylor LP, Hepler PK (1997) Pollen germination and tube growth. Ann Rev Plant Phys Plant Mol Biol 48: 461-491

74. Dorne AJ, Kappler R, Kristen U, Heinz E (1998) Lipid metabolism during germination of tobacco pollen. Phytochemistry 27: 2027-2031

75. Rodríguez-García MI, Fernández MC (1990) Ultrastructural evidence of endoplasmic reticulum changes during the maturation of the olive pollen grain (Olea europaea L., Oleaceae). Plant Syst Evol 171: 221-231

76. Müller AO, Ischebeck T (2018) Characterization of the enzymatic activity and physiological function of the lipid droplet-associated triacylglycerol lipase AtOBL1. New Phytol 217: 1062-1076

77. Rejón JD, Zienkiewicz A, Rodríguez-García MI, Castro AJ (2002) Profiling and functional classification of esterases in olive (Olea europaea) pollen during germination. Ann Bot 110: 1035-1045

78. Brocard L, Immel F, Coulon D, Esnay N, Tuphile K, Pascal S, Claverol S, Fouillen L, Bessoule JJ, Bréhélin C (2017) Proteomic analysis of lipid droplets from arabidopsis aging leaves brings new insight into their biogenesis and functions. Front Plant Sci 8: 894 
79. Gidda SK, Park S, Pyc M, Yurchenko O, Cai Y, Wu P, Andrews DW, Chapman KD, Dyer JM, Mullen RT (2016) Lipid droplet-associated proteins (ldaps) are required for the dynamic regulation of neutral lipid compartmentation in plant cells. Plant Physiol 170: 2052-2071

80. Pyc M, Gidda SK, Seay D, Esnay N, Kretzschmar FK, Cai Y, Doner NM, Greer MS, Hull JJ, Coulon D, Bréhélin C, Yurchenko O, de Vries J, Valerius O, Braus GH, Ischebeck T, Chapman KD, Dyer JM, Mullen RT (2021) LDIP Cooperates with SEIPIN and LDAP to Facilitate Lipid Droplet Biogenesis in Arabidopsis. Plant Cell (in press)

81. Lu J, Xu Y, Wang J, Singer SD, Chen G (2020) The Role of Triacylglycerol in Plant Stress Response. Plants (Basel) 9: 472

82. Higashi Y, Okazaki Y, Takano K, Myouga F, Shinozaki K, Knoch E, Fukushima A, Saito K (2018) HEAT INDUCIBLE LIPASE 1 remodels chloroplastic monogalactosyldiacylglycerol by liberating a-linolenic acid in arabidopsis leaves under heat stress. Plant Cell 30: 1887-1905

83. Arisz SA, Heo JY, Koevoets IT, Zhao T, van Egmond P, Meyer AJ, Zeng W, Niu X, Wang B, Mitchell-Olds T, Schranz ME, Testerink C (2018) Diacylglycerol acyltransferase 1 contributes to freezing tolerance. Plant Physiol 177: 1410-1424

84. Tan WJ, Yang YC, Zhou Y, Huang LP, Xu L, Chen QF, Yu LJ, Xiao $S$ (2018) Diacylglycerol acyltransferase and diacylglycerol kinase modulate triacylglycerol and phosphatidic acid production in the plant response to freezing stress. Plant Physiol 177: 1303-1318

85. Aubert $Y$, Vile D, Pervent M, Aldon D, Ranty B, Simonneau T, Vavasseur A, Galaud JP (2010) RD20, a stress-inducible caleosin, participates in stomatal control, transpiration and drought tolerance in Arabidopsis thaliana. Plant Cell Physiol 51: 1975-1987

86. Hanano A, Bessoule JJ, Heitz T, Blée E (2015) Involvement of the caleosin/peroxygenase RD20 in the control of cell death during Arabidopsis responses to pathogens. Plant Signal Behav 10: e991574

87. Shimada TL, Takano Y, Hara-Nishimura I (2015) Oil body-mediated defense against fungi: From tissues to ecology. Plant Signal Behav 10: p. e989036

88. Fernández-Santos R, Izquierdo Y, López A, Muñiz L, Martínez M, Cascón T, Hamberg M, Castresana C (2020) Protein profiles of lipid droplets during the hypersensitive defense response of arabidopsis against pseudomonas infection. Plant Cell Physiol 61: 1144-1157

89. Gudesblat GE, Torres PS, Vojnov AA (2009) Stomata and pathogens: Warfare at the gates. Plant Signal Behav 4: 1114-1116.

90. McLachlan DH, Lan J, Geilfus CM, Dodd AN, Larson T, Baker A, Hõrak H, Kollist H, He Z, Graham I, Mickelbart MV, Hetherington AM (2016) The breakdown of stored triacylglycerols is required during light-induced stomatal opening. Curr Biol 26: 707-712

91. Yang LN, Liu H, Wang YP, Seematti J, Grenville-Briggs LJ, Wang Z, Zhan J (2021) Pathogen-mediated stomatal opening: a previously overlooked pathogenicity strategy in the oomycete pathogen phytophthora infestans. Front Plant Sci 12: 668797 


\section{Tu, tam i wszędzie - znaczenie lipidów neutralnych we wzroście i rozwoju roślin}

\section{Agnieszka Zienkiewicz, Marta Saldat, Krzysztof Zienkiewicz ${ }^{\bowtie}$}

Interdyscyplinarne Centrum Nowoczesnych Technologii, Uniwersytet Mikołaja Kopernika w Toruniu

$\bowtie$ Autor korespondujący: kzienk@umk.pl

Słowa kluczowe: krople tłuszczu, tracyloglicerole, lipidy neutralne, nasiono, pyłek, starzenie się liści

\section{STRESZCZENIE}

U roślin, tłuszcze stanowią jeden z podstawowych składników komórek. Lipidy neutralne odgrywają podstawową rolę w cyklu życiowym rośliny, ponieważ służą jako jedno z podstawowych źródeł węgla i energii podczas intensywnych metabolicznie okresów wzrostu i rozwoju. Najpowszechniejszą formą chemiczną magazynowania tłuszczy są triacyloglicerole (TAGs), zmagazynowane w wyspecjalizowanych organellach komórkowych określanych mianem kropli tłuszczu (z ang. lipid droplets, LDs). Organelle te identyfikowano w różnych organach i tkankach roślinnych, jak nasiona czy ziarna pyłku. Krople tłuszczu składają się z rdzenia tworzonego przez triacyloglicerole i ograniczone są pojedynczą błoną fosfolipidową, zasocjowaną ze ściśle określonymi białkami strukturalnymi. Niedawny postęp w badaniach nad proteomem kropli tłuszczu zaowocował także identyfikacją wielu innych białek wchodzących $w$ interakcje z tymi organellami. Jest to zapewne odzwierciedlenie ich wysoce dynamicznego charakteru i zaangażowania w wiele różnych aspektów metabolizmu komórkowego, ściśle zsynchronizowanych z programami rozwojowymi rośliny, a także bezpośrednio związanych z oddziaływaniami roślina-środowisko. Niniejsza praca przeglądowa podsumowuje i poddaje dyskusji obecny progres w zrozumieniu roli kropel tłuszczu oraz zgromadzonych w nich molekuł podczas cyklu życiowego rośliny, ze specjalnym uwzględnieniem aspektów rozwojowych.

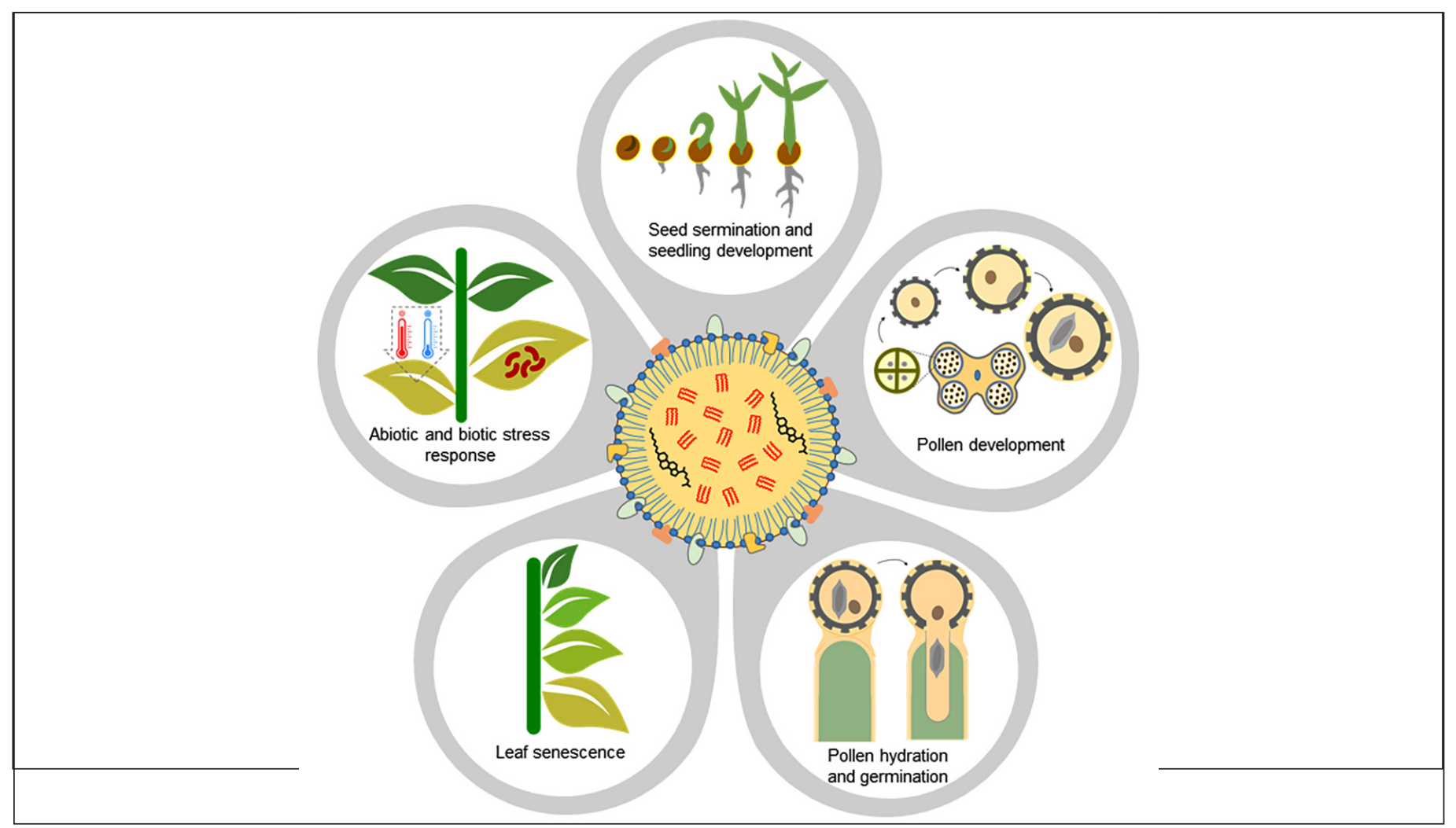

